\title{
“VOCÊ É A DORA? EU SOU O GUIMARÃES ROSA": ENCONTROS MÍTICOS DO ESCRITOR MINEIRO COM A POETA PAULISTA DORA FERREIRA DA SILVA
} Enivalda Nunes Freitas e
Souza* *eni@ufu.br

Doutora em Literatura Brasileira (USP). Pós-Doutorado em Estudos Literários (UFMG). Universidade Federal de Uberlândia.

RÉSUMÉ: Le but de cet article est d’examiner une visite de Guimarães Rosa chez poète pauliste Dora Ferreira da Silva et les Guimaräes Rosa chez poète pauliste Dora Ferreira da Siva et les développements de celui-là rencontre, tel que lettres du écrivain de Minas Gerais et deux poèmes de Dora à Guimarães Rosa. L'analyse de poèmes rèvéle la proximité entre la pensée des deux écrivains, sourtout lors de la conception de l' univer comme une unité symbolique et à la croyance dans le pouvoir transformateur de la langue. C'est par la voie du mythe - le mythe de Orpheu - que la poéte se reencontre, encore une fois, avec Rosa monté que la poen cheval, mantenant à travers d une photo. Le Chevalier regardant en ariere arrac Le Chevaler regantant en vraie transposition des espaces, sauvant le temps primordial que l'art permet. L'apport theorique de ce travail vien des entretiens et des oeuvres des deux écrivains, outre des études sur le mythe de Mircea Eliade et Carl Gustav Jung.

MOTS-CLÉS: Dora Ferreira da Silva; Guimarães Rosa; mythe; langue; poésie. 
Foi assim, - "Você é a Dora? Eu sou o Guimarães Rosa" -, com voz clara e montado em cavalo, que João Guimarães Rosa se anunciou à poeta Dora Ferreira da Silva (1918-2006), em sua casa da Rua José Clemente, São Paulo, "lá pelas 15 horas de 1957". De repente, todo o sertão bate à porta e invade a sala, suspendendo o tempo profano para estabelecer o tempo do mito. Naturalmente, Rosa não estava montado em cavalo, mas essa foi a impressão que o escritor mineiro causou à poeta paulista naquela visita inesperada, quando ela e o esposo, o filósofo Vicente Ferreira da Silva, preparavam uma das primeiras obras de crítica ao Grande sertão: vereda (1956), a Diálogo no 8 (1957), toda ela dedicada a Guimarães Rosa. No depoimento ao Cadernos de Literatura Brasileira João Guimarães Rosa (IMS, dezembro de 2006), Dora relata, ainda, que o escritor trouxera-lhe "uma pequena cabeça de boi esculpida num osso, como presente de jagunço", gesto que a encantou: "era um verdadeiro presente digno de Diadorim”. Entre “conversas e reconversas”, Guimarães Rosa fala de sua religio, de questões metafísicas, em voz que ressoa "no Mundo", voz e presença hierofânicas, reafirmando na poeta o que lhe era mais caro, o sentido do sagrado:

A frase forte e impressionante daquele escritor consagrado ressoou na sala, no Mundo: "Sou só religião, alheio a qualquer associação ou organização religiosa”, e completou falando de sua tentativa de manter um diálogo sem mediações com o in- finito. [...] Tudo em Guimarães Rosa soava com pureza, havia nele algo inconfundível, o gosto do que é amplo e verdadeiro. A minha visão do nosso grande bardo fundiu-se com aquela tarde quente e inesperada, e tornou-se a alegria inesquecível de um encontro autêntico. ${ }^{1}$

Sentado em um sofá, Rosa ouve da poeta o artigo que publicaria na Diálogo 8 (1957), "O demoníaco em Grande sertão: veredas”. Dora discorre sobre o terror que a ambiguidade do diabo - dá provas de existência e de não existência - inspira em Riobaldo, uma vez que o demo pode estar numa "aragem sagrada" ou numa pedra venenosa, ou pode ser apenas um dos aspectos do homem. Por fim, a negatividade positiva do diabo que está em tudo e pode irromper a qualquer momento faz da travessia do humano uma catábase, o que torna o demoníaco na vida de Riobaldo uma encenação arquetípica que repete a travessia astral pontuada por nascimento, ascensão e declínio:

E o que é essa travessia do homem humano senão a repetição do mito astral, o caminho do sol que envolve em seu percurso nascimento, ascensão e declínio, itinerário criador do dia e da noite, luta com os demônios e purificação? ${ }^{2}$

A poeta finaliza a análise do romance pontuando que o herói deve conhecer as "dificuldades e asperezas" do caminho
1. SILVA. Às margens de Rosa, p. 60.

SILVA. O demoniaco em Grande Sertão: Veredas, p. 33.
EM TESE
BELO HORIZONTE
v. 22
N. 2
MAIO-AGO. 2016
SOUZA. "Você é a Dora? Eu sou o Guimarães Rosa”: encontros míticos [...] P. 157-174 
que levará à compreensão de si mesmo. Vale lembrar que, um ano depois da publicação da obra, a crítica ainda fazia seus primeiros esforços para compreendê-la. Segundo Dora Ferreira da Silva, todo o texto foi lido com o coração "batendo forte", e Guimarães Rosa teria dito à poeta que ninguém mais poderia escrever sobre o Grande sertão: veredas sem passar pela sua análise. Aquele número da Diálogo tornou-se indispensável para a compreensão do universo rosiano. Os artigos de Dora e Vicente Ferreira da Silva se completam com os de Antonio Candido, Milton Vargas, Efrain Tomás Bó, Olívia Krtihenbühl, Roberto Simões, Paulo Dantas, Luiz Costa Lima Filho, Renata Pallotini e J. B. Martins Ramos. O artigo de Dora recebeu uma bela ilustração de Aldemir Martins (Aurora - CE, 8 de novembro de 1922 / São Paulo, 5 de fevereiro de 2006), relativa àquela cena em que Diadorim corta o cabelo de Riobaldo às margens do Rio das Velhas. Na referida ilustração, Diadorim empunha uma tesoura afiada, enquanto Riobaldo, sentado em uma pedra, de perfil, não mostra o rosto. Flores delicadas compõem o quadro.

Guimarães Rosa fora ali interessadíssimo na revista direcionada à sua obra. Dora Ferreira da Silva, àquela altura nem tinha publicado seu primeiro livro, ainda que escrevesse poesias desde 1948. Andanças (1970) sairia mais de dez anos depois do encontro com Rosa. Dora era tradutora e esposa do filósofo Vicente Ferreira da Silva, e assinava como Dora Mariana Ribeiro Ferreira da Silva. A partir da década de 50, a casa ajardinada dos Ferreira da Silva, na rua José Clemente, em São Paulo, passa a receber com frequência pessoas interessadas em cultura, para ler e discutir poesia, filosofia, religião, arte, ouvir música. Dora fala que as reuniões eram informais e compostas por pessoas de variadas formações: "Tudo muito informal, sem periodicidade. Juntavam-se as pessoas mais díspares e as coisas aconteciam espontaneamente. Muitas vezes, o Vicente fazia conferências ou lia parte dos seus escritos". ${ }^{3}$ Dora lembra um dado importante dessas reuniões: professores europeus que vinham ministrar curso na USP também "passavam por ali". Como resultado do entusiasmo e compromisso que reinavam nesses encontros, surgem as revistas Diálogo (19551963) e Cavalo Azul (1964/1965-1989). A primeira revista que alcançou dezesseis edições, foi fundada com seu marido, o filósofo Vicente Ferreira da Silva, e com Milton Vargas, dando enfoque às ciências humanas. Já a revista Cavalo $A z u l$, criada com a colaboração de Vilém Flusser e Anatol Rosenfeld, após a morte prematura de Vicente, voltou-se mais para as artes e a literatura, alcançando doze edições. A última edição é constituída pelos no 11 e 12 . Essas revistas foram imprescindíveis para o meio intelectual daquele momento por trazerem ensaios sobre variados temas e autores. Era nelas que Dora Ferreira da Silva publicava os poetas que traduzia. O valor de suas traduções é de ordem inestimável
3. GALVÃO. Entrevista de Dora Ferreira da Silva.
EM TESE
BELO HORIZONTE
v. 22
MAIO-AGO. 2016
SOUZA. "Você é a Dora? Eu sou o Guimarães Rosa”: encontros míticos [...] P. 157-174

N. 2 
4. GALVÃO; MARTINS. Dora Ferreira da Silva: diálogos sobre poesia e filosofia, recordando Vicente Ferreira da Silva.

5. GALVÃO. Entrevista de Dora Ferreira da Silva. para a cultura da época, quando ainda não se contava com o intercâmbio facilitado pelos recursos da internet, quando autores relevantes de língua estrangeira eram escassos nas livrarias. Dora declara, em entrevista a Donizete Galvão e Floriano Martins, que tivera que traduzir Novalis para o marido, o filósofo Vicente Ferreira da Silva, em função da carência de determinadas obras literárias na cidade: "Em São Paulo, não havia livros de Novalis. As editoras não se arriscavam. Quem iria ler Novalis?"

\section{ROSA À CAVALO AZUL}

Guimarães Rosa teria ido três vezes à casa de Dora e Vicente para as tertúlias literárias, além de ter enviado o conto "As garças" para a Cavalo Azul 1:

Guimarães Rosa colaborou com um conto magnífico chamado "As garças". Veio três vezes a esta casa da Rua José Clemente. As pessoas eram avisadas por telefone e todos compareciam. Um homem fascinante, muito aberto. Sempre alegre, elegante como um diplomata. [...] Dedicamos o número 8 inteiro de Diálogo à sua obra.

Dora explica que a revista Cavalo Azul "foi inspirada nos cavalos etruscos que conduzem os mortos para o outro mundo". Nesse sentido, é preciso elucidar que Dora Ferreira da Silva sempre teve fascínio pela escuridão, pelo desconhecido, pelo sombrio, elementos que constituem os aspectos inexplorados do inconsciente e que são associados ao mito de Perséfone, a personificação dos opostos que forçosa e necessariamente se unem para constituir a totalidade do ser. Ao explicar o nome da revista, a poeta escreve: "É espantoso como a palavra diz a coisa, vai ao núcleo do imponderável.”. ${ }^{6}$ A Cavalo Azul 1 é aberta com uma epígrafe de Dora informando o sentido simbólico do cavalo azul, o estar entre dois mundos que se faz representar pelas alternâncias das patas dos cavalos ora projetadas ao ar ora ferindo a terra: "CAVALO AZUL, nossa radicação, nossa pertinência à Terra. Mas os antigos já sabiam que o cavalo é e não é desta terra: as pontas das quatro patas tocam levemente o chão, para alçar vôo".

O número 1 da Cavalo Azul saiu no final de 1964 ou no início de 1965. A data precisa ainda não pôde ser apurada. De todo modo, "As garças" foi publicado no Suplemento Literário de O Estado de São Paulo em 22 de fevereiro de 1964. Portanto, a revista de Dora não teve a primazia do ineditismo do conto.

\section{ROSA ESCREVE A VICENTE}

A partir daquele encontro, a amizade e o diálogo de Rosa com os Ferreira da Silva foram estabelecidos. Começam as cartas. Respaldado pela cordialidade entre ambos, Rosa
6. GALVÃO. Entrevista de Dora Ferreira da Silva.
EM TESE
BELO HORIZONTE
v. 22
N. 2
MAIO-AG0. 2016
SOUZA. "Você é a Dora? Eu sou o Guimarães Rosa": encontros míticos [...] P. 157-174 
7. GALVÃO; MARTINS. Dora Ferreira da Silva: diálogos sobre poesia e filosofia, recordando Vicente Ferreira da Silva.

8. GALVÃO; MARTINS. Dora Ferreira da Silva: diálogos sobre poesia e filosofia, recordando Vicente Ferreira da Silva.

9. GALVÃO; MARTINS. Dora Ferreira da Silva: diálogos sobre poesia e filosofia, recordando Vicente Ferreira da Silva. escreve a Vicente dando continuidade a uma conversa, sugerindo ao filósofo que leia "o Corpo de baile inteiro" e "quem sabe, reler também Grande Sertão: Veredas" para que possam conversar e reconversar em "horas vastas", pessoalmente, porque "Em carta a gente se desentende. Nisto, como em tudo mais, o que vale são os detalhes e o calor da vida". Nessa carta a Vicente Ferreira da Silva, Guimarães Rosa teoriza sobre a orientação filosófica do Grande sertão: veredas que, segundo o autor, seria superior ao arranjo literário romanesco: "por bizarra que você ache a afirmação, é menos literatura pura do que um sumário de idéias e crenças do autor com buritis e capim devidamente semicamuflados". A conjunção da física com a metafísica, o exercício de imprimir ao gênero romanesco uma densa e bem elaborada filosofia, tudo isso já foi amplamente estudado em Rosa. O trecho supracitado aparece na carta que Dora lê na entrevista que teve com Donizete Galvão e Floriano Martins intitulada "Dora Ferreira da Silva: diálogos sobre poesia e filosofia, recordando Vicente Ferreira da Silva". ${ }^{8}$ Rosa cita os filósofos Berdiaeff, “formidável”, Jaspers, Kierkegaard, e aponta sua linha de pesquisa: "Principalmente, porém, estou nesta cintilante linha: Platão, Bergson, Berdiaeff, Cristo". ${ }^{9}$ Nessa mesma carta a Vicente Ferreira da Silva, Guimarães Rosa fala que é individualista, que tem "aversão ao histórico, ao político, ao sociológico", que "a vida neste planeta é caos, queda, desordem essencial, irremediável aqui. Tudo fora de foco" e que o intelectual o repugna, deixando claro que o que conta, mesmo, é a busca da plenitude: "Zurück (para trás) nunca. Para coisa nenhuma. Só hinauf (para cima). A busca da plenitude: um fato".$^{10} \mathrm{O}$ escritor mineiro explica a Vicente pontos fundamentais de sua concepção religiosa, destacando o papel do Cristo verdadeiro, cujos ensinamentos podem dar invulnerabilidade ao homem. O trecho seguinte que dá continuidade ao teor da carta contém a frase "Sei que haverá 'novos' deuses". Como essa sentença não aparece na referida carta lida na entrevista, pincei-a do depoimento de Dora ao Cadernos de Literatura Brasileira - João Guimarães Rosa:

Sei que haverá “novos” Deuses, mas tudo que é discórdia, agressividade, destrutividade, tem de se transformar, desaparecer antes. Cristo, (o Cristo verdadeiro), cabe; tem seu ensino, indispensável.

"Os mansos herdarão a Terra." Seu ensino central, a meu ver (o do Reino do céu dentro de nós) é: 1 - o domínio da natureza, a começar pela natureza de cada um - pela fé, que é a forma mais alta e sutil de energia, à qual o universo é plástico; 2 - o amor, possibilitando a coexistência, sem o mínimo sinal de atrito, conflito, desarmonia, destruição ou desperdício. Sobre esta plataforma, o céu, as possibilidades infinitas de um sempre evoluir em plenitude, prazer, alegria ininterrupta; cada um invulnerável. ${ }^{11}$
10. GALVÃO; MARTINS. Dora Ferreira da Silva: diálogos sobre poesia e filosofia, recordando Vicente Ferreira da Silva.
EM TESE
BELO HORIZONTE
v. 22
N. 2
MAIO-AGO. 2016
SOUZA. "Você é a Dora? Eu sou o Guimarães Rosa”: encontros míticos [... ] P. 157-174 
Dora compreende bem a religio de Guimarães Rosa porque comunga da mesma crença: a arte a serviço da transformação do homem, a natureza se oferecendo como participação mística e os opostos se reconciliando. Tanto para Dora quanto para Rosa, a poesia - a palavra poética - se configura como abertura ao Mistério, espaço em que a palavra é criação.

\section{ROSA ESCREVE A DORA}

Em 1958, já publicado o número especial da Diálogo 8 dedicado ao autor de Grande sertão: veredas, Guimarães Rosa escreve a Dora Ferreira da Silva referindo-se aos encontros na casa da Rua José Clemente com bastante entusiasmo, não se esquecendo da irmã de Dora, Diva, nem do amigo e colaborador das revistas e encontros, Milton Vargas. Rosa chama a casa da rua José Clemente de "sala 'européia', casa do espírito, da calma alegria e amizade”. Diz que a Diálogo 8 foi um "ouro" que eles lhe deram; relembra embates e interpelações com o esposo de Dora, "Grande Vicente, de pé, sempre para lá e para cá, sempre com aquele ótimo sorriso: entre de chinês e de um professor de Tubingen ou Darmstadt" e envia artigos publicados no Rio a respeito de sua obra, sugerindo que sejam encaminhados ao "grande Antonio Candido". Eis a carta na íntegra:
Rio, 19 de fevereiro de 1958

Dora

Sempre em viva simpatia com Vocês, continuo criando mais lembrança dessa sala "européia", casa do espírito, da calma alegria e amizade. Guardei-os. (E a Diva!)

Decoro o "Diálogo - 8", em horas de baixa ou desânimo, e pulo de novo, todo folhagem. Que grande ouro Vocês me deram!

Li, reli, o ensaio de Vicente (no "Jornal do Comércio"), admirando. Sorri, também, ao descobrir que aquelas seguidas e agudas interpelações com que ele me crivava, aí, de certo modo não passavam de conferência ou arguta recapitulação do tema - do estudo àquela hora pronto, talvez todo já escrito, e que tensamente ocupava seu pensamento todo de pensador. Grande Vicente, de pé, sempre para lá e para cá, sempre com aquele ótimo sorriso: entre de chinês e de um professor de Tubingen ou Darmstadt.

Quanto à tese que aí, em puro, discutimos, vou retomá-la ainda com Vocês, em livre, ousada - isto é, ingênua - loquacidade. Quer-me parecer, por ora, que é uma grande antítese. E a síntese? Gosto de achar que tudo evolui e avança necessariamente bem: o antigo individualismo, externo, era apenas uma antecipação, obrigatória, mas que precisava ser superada. Os cimos e montanhas tinham de corroer-se, demolir-se, num nivela- 
12. SOUZA. Flores de Perséfone: a poesia de Dora Ferreira da Silva e o sagrado, p. 36. mento só aparentemente regressivo ou desanimador. Aquilo era contundente, anárquico, infernal e fora de lugar. Pesava contra a harmonia. Mas o nivelamento, em verdade, modela apenas a superfície: lisa, simples, harmoniosa, como teria de vir a ser. E a projeção individual, a absoluta originalidade, de cada um, passarão a poder seu em profundidade, no lugar certo. O que havia, e que admirávamos, estava, agora, (repito: estava agora) bordado no avesso; e tem de ser rebordado do lado direito. Vocês me entendem? O reino da individualidade não pode, não deve ser "deste mundo", e sim em outro plano, acima, no mundo da poesia, Céu, "existência simbólica".

Bem, já disparei, me alonguei, confuso. Vocês me perdoem.

Como não sei se leram este artigo de F. de Oliveira, saído aqui em tempo de Carnaval, junto envio dois recortes - pois talvez gostem de fazer chegar um deles às mãos do grande Antonio Candido.

Abraço vocês, muito. E Diva. E Milton Vargas, amigo. E tudo, e todos.

Guimarães Rosa ${ }^{12}$

É interessante observar que Guimarães Rosa retoma a questão do individualismo que já pronunciara na carta anterior e que certamente rendera boas discussões com os amigos. Nessa carta, o escritor volta a insistir na importância da individualidade porque esta garante a absoluta genialidade de cada um daí que o reino da individualidade seja o da poesia. A individualidade se projeta como os cimos e as montanhas. Quando nivelados, o são apenas superficialmente, uma vez que guardam toda a dimensão original. Assim, a postura individua se afigura como projeção simbólica da profundidade de cada um. Quanto ao artigo de Franklin de Oliveira (1916-2000), membro da Academia Brasileira de Letras, jornalista consagrado e crítico literário, que recebeu o Prêmio Machado de Assis pelo conjunto da obra, Rosa deve estar se referindo ao artigo "Revolução Rosiana", ${ }^{13}$ publicado no Correio da Manhã, de quem F. de Oliveira era editor, no dia 26 de novembro de 1967. Caso seja esse o texto mencionado por Rosa, ou a indicação ao final do artigo refere-se tão somente à data da escrita ou o "tempo de Carnaval" apontado pelo escritor mineiro não passa de uma metáfora para dias festivos.

\section{O ALQUIMISTA E A SIBILA}

O trabalho de Dora Ferreira da Silva como tradutora, ensaísta e diretora da Cavalo Azul sempre esteve atrelado a autores de sua mesma família poética, ou seja, aqueles que entendiam a literatura - sobretudo a poesia - compromissada com valores perenes ao homem. Assim, sentiu-se estimulada a traduzir Carl Gustav Jung, cujo pensamento se estendeu à sua vida e à sua poesia. De igual modo, Rainer Maria Rilke, D. H. Lawrence, San Juan de la Cruz, Angelus Silesius, Saint John Perse ressoaram elementos indissociáveis de sua
13. OLIVEIRA. Revolução rosiana, p. 179-186. 
poesia, como a "noite escura da alma", a vida como passagem, a desmaterialização do cotidiano - a libertação da vida aprisionada -, o sentido do infinito no efêmero, a participação mística, o inconsciente como energia propícia à criação.

Dora acredita na palavra como "sopro cosmogônico", capaz de promover a integração do mundo despedaçado e restabelecer sua ordem, restituindo ao poeta o título de vidente e demiurgo, aquele que ilumina o caminho e não deixa a chama da vida apagar. A poeta crê na mediação divina da palavra poética. Com a bênção dos deuses, a palavra poética (profética), de inconfundível tom sacral, será sempre única, misteriosa, apta a recriar o mundo após cada realização. O poeta deve buscar a linguagem que antecede toda a criação. O poeta é criador, um coautor de Deus no exercício da fundação:

\section{$\mathrm{V}$}

No princípio, o Poema:

Voz e partitura

cantavam-se.

Ouviam-no

longínquas estrelas.

A solidão

não nascer

nem vales verdes

nenhuma flor ou pássaro.

Os deuses despertaram. ${ }^{14}$
O poema é anterior a todas as coisas e o princípio de tudo o que existe: é a linguagem que recria os vales, a flor, o pássaro e a solidão. Assim como Deus é o Verbo que precede a fundação, o poema é o resgate e a orquestração da unidade cósmica, quando palavra e existência se correspondem - "Voz e partitura" -, cujo som encantatório acorda os deuses e os desperta para a criação. Guimarães Rosa irá dizer: "Somente renovando a língua é que se pode renovar o mundo" e "O som e o sentido de uma palavra pertencem um ao outro". ${ }^{15}$ Esse fascínio da poeta pelo sagrado deve-se a uma nostalgia do tempo mítico, quando, numa expressão rosiana, "tudo era falante".

O leitor de Guimarães Rosa logo vê que a postura de Dora Ferreira da Silva sobre a linguagem poética se avizinha da obra do fabulista mineiro. Basta percorrer a entrevista com Gunter Lorenz para localizar declaradamente aquilo que se dá em sua obra. Podemos recordar que Rosa dava peso à inspiração:

Não preciso inventar contos, eles vêm a mim, me obrigam a escrevê-los. Acontece-me algo assim como vocês dizem em alemão: Mich reitet auf einmal der Teufel [De repente o diabo me cavalga], que neste caso se chama precisamente inspiração. ${ }^{16}$

Rosa também professava o poder redentor da literatura, o que exigia responsabilidade do escritor para com os homens:
15. ROSA. Fiç̧ão completa, p. 88.

16. ROSA. Fiç̧ão completa, p. 71
EM TESE BELO HORIZONTE

v. 22

N. 2

MAIO-AGO. 2016

SOUZA. "Você é a Dora? Eu sou o Guimarães Rosa”: encontros míticos [...] P. 157-174 
18. ROSA. Ficção completa, p. 81.

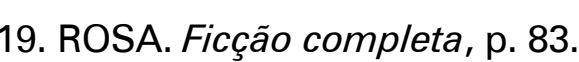

Credo e poética são uma mesma coisa. [...] A vida deve fazer justiça à obra e a obra à vida. Um escritor que não se atém a esta regra não vale nada, nem como homem nem como escritor. Ele está face a face com o infinito e é responsável perante o homem e perante si mesmo. ${ }^{17}$

Páginas adiante, Rosa vai dizer que o bom escritor "é um arquiteto da alma", que "o caráter do homem é seu estilo, sua linguagem", que o idioma é uma "metáfora da sinceridade”, que a língua é seu "elemento metafísico" e que seu método consiste "na utilização de cada palavra como se ela tivesse acabado de nascer, para limpá-la das impurezas da linguagem cotidiana e reduzi-la a seu sentido original". ${ }^{18}$ As declarações de Rosa sobre a linguagem não cessam: "a linguagem e a vida são uma coisa só", "o idioma é a única porta para o infinito", "a língua e eu somos um casal de amantes" e, mais uma vez, insiste no trabalho de devolver à palavra seu sentido original, fundante:

O bem-estar do homem depende do descobrimento do soro contra a varíola e as picadas de cobras, mas também depende de que ele devolva à palavra seu sentido original. Meditando sobre a palavra, ele se descobre a si mesmo. Com isso repete o processo da criação. ${ }^{19}$

Pouco a pouco, Rosa vai chegando às fontes inconscientes da linguagem, suas bases pré-conscientes, opostas à lógica, quando a poesia se confunde com a magia e se faz uma "aventura do desconhecido", brotando do inconsciente e do irracional: "por isso também espero uma literatura tão ilógica como a minha, que transforme o cosmo num sertão no qual a única realidade seja o inacreditável”. ${ }^{20} \mathrm{O}$ esforço da poesia de Dora Ferreira da Silva também foi o de alcançar a realidade invisível que cerca o homem, inclinação presente em sua obra desde o primeiro livro, Andanças (1970). Esse projeto, que é também compartilhado por Rainer Maria Rilke, foi-se ampliando com a tradução de Jung e dos poetas místicos. Dora chegou a escrever um ensaio sobre o poder da palavra poética de abrir caminho às profundezas inconscientes em busca das vivências primordiais que levam à abertura mística: "O poeta mergulha no profundo do inconsciente, tocando às vezes níveis impessoais, extremamente arcaicos”. ${ }^{2}$

\section{MITO, A MORADA DO HOMO RELIGIOSUS}

O Guimarães Rosa que é "só religião" exemplifica o que Mircea Eliade compreende sobre o homo religiosus: aquele que acredita em uma realidade que transcende a que se manifesta neste mundo, que crê que a vida tem uma origem sagrada, que sua existência "é alimentada por pulsões que lhe chegam do mais profundo de seu ser, da zona que se chamou de inconsciente". ${ }^{22}$ Rosa sempre advogou o desprimado da razão em favor da magia intuitiva, da inspiração e do mistério. Ele queria livros anti-intelectuais, provindos da
20. ROSA. Fiç̧ão completa, p. 93.

21. SILVA; LEPARGNEUR. Angelus Silesius: a mediação do nad , p. 28

22. ELIADE. O sagrado e o profano p. 170.
EM TESE
BELO HORIZONTE
v. 22
N. 2
MAIO-AGO. 2016
SOUZA. "Você é a Dora? Eu sou o Guimarães Rosa”: encontros míticos [...] P. 157-174 
memória e da sensação reveladoras, conforme declara a seu entrevistador Günter Lorenz:

A lógica é a prudência convertida em ciência; por isso não serve para nada. Deixa de lado componentes importantes, pois, quer se queira quer não, o homem não é composto apenas de cérebro. Eu diria mesmo que, para a maioria das pessoas, e não me excetuo, o cérebro tem pouca importância no decorrer da vida. O contrário seria terrível: a vida ficaria limitada a uma única operação matemática, que não necessitaria da aventura do desconhecido e inconsciente, nem do irracional. ${ }^{23}$

O autor consagrou-se pela exploração da coincidentia opositorum, quando os pares antitéticos já não mais existem e tudo pode ser e não ser, como no mundo das imagens simbólicas do mito. E pela força do mito que o sertão é o mundo, regido por um tempo cíclico, quando o homem repete, com força fundante, gestos modelares que reatualizam sua integração no tempo primordial, o tempo da origem.

Dora Ferreira da Silva relata que, quando criança, sua babá costumava folhear uma revista italiana que tinha imagens de pirâmides e esfinges. Ela ficava olhando, não sabia o que aquilo significava, mas era atraída pelas imagens, que a chamavam, que a tocavam fundo. Esse teria sido o primeiro encontro da poeta com o mito, o qual lhe exerceria fascínio pelo resto da vida.
O mito é, em sua origem, uma forma de conhecimento que privilegia o onírico, o inconsciente, as infinitas possibilidades de se chegar a um aspecto de nossa vida sem passar pelo viés da razão. Daí a proximidade do mito com a poesia, se considerarmos esta como uma arte que se estreita com a fantasia e a imaginação num movimento que transcende a realidade e coletiviza o sujeito, ainda que sempre ligada a eles. Poesia e mito têm a capacidade de repercutir no infinito e perdurar o instante, além de ser uma forma de conhecimento para o homem. O mito explica como é que as coisas passaram a existir: "O mito conta uma história sagrada; ele relata um acontecimento ocorrido no tempo primordial, o tempo fabuloso do princípio". ${ }^{24}$ Outro teórico completa a definição de mito: "propõe modelos e paradigmas de comportamento; projeta o homem num tempo que precede o tempo; situa a história e os empreendimentos humanos num espaço indimensionável”. ${ }^{25} \mathrm{~A}$ própria Dora elucidou o conceito de mito, acrescentando a importante ideia de que o mito está dentro de nós mesmos:

Ele vem do mais profundo da psique, é uma emanação do nosso pensamento não codificado. Nós o encontramos, por exemplo, quando dormimos e sonhamos, o artista vai buscá-lo na dimensão do onírico, motivos para a sua poesia; é como um tomar posse daquilo que foi exteriorizado, partindo de si próprio, buscando lá dentro, nestes depósitos secretos que temos em nosso interior... ${ }^{26}$
24. ELIADE. Mito e realidade, p. 11-13.

25. CRIPPA. Mito e cultura, p. 15

26. NERY. Dora Ferreira da Silva: a fascinação do mito. 
27. JUNG. O espírito na arte e na ciência, p. 86.

30. JUNG. Símbolos da transformação, p. 21
Um mito não se esgota porque ele é a expressão de conteúdos que estão armazenados em nosso inconsciente, os chamados arquétipos. Arquétipo pode ser sinônimo de "ideia", diz respeito a determinadas formas na psique que estão presentes em todo tempo e em todo lugar. Os mitos expressam esses arquétipos. $\mathrm{O}$ homem e o arttista reinventam os mitos porque a alma humana é sempre a mesma. É pela capacidade criativa de um artista que um mito sobrevive enquanto objeto estético: um mesmo mito pode ser recontado infinitas vezes. ${ }^{27}$

$\mathrm{Na}$ literatura, identificamos determinados estratos míticos pela evocação explícita que a obra faz a eles, como título, encadeamento de ações - a estrutura narrativa - ou imagens, as que chamamos imagens arquetípicas, como sombras, água, música, árvore, jardim, igreja, sol. Cada imagem poderá evocar um mito particularizado ou muitos deles. Por exemplo, sombras e água podem remeter a Narciso, mas sombras também evocam, além de Narciso, Perséfone e Orfeu; a imagem da água vai das águas maternas e primaveris, aquelas de purificação e regeneração, até a evocação da morte de Narciso e Ofélia. Já um barco nas águas pode lembrar ao leitor a nau dos insensatos, Caronte, e toda uma constelação de águas perigosas.

Todos os povos e culturas criam e cultivam seus mitos O psicólogo Carl Gustav Jung chega a dizer que "aquele que pensa viver sem mito ou fora dele constitui uma exceção.
É um erradicado”. ${ }^{28}$ Quando um indivíduo sonha, ele está ativando ou reelaborando seus próprios mitos - aqueles que lhe são importantes - e os mitos são individuais e coletivos ao mesmo tempo. Jung ainda lembra que "o mito é o sonho coletivo do povo, [...] são restos desfigurados de fantasias correspondentes a desejos de nações inteiras". ${ }^{29}$ É por isso que encontramos poemas, romances, obras de arte, enfim, quaisquer produtos artísticos muito parecidos uns com os outros, mesmo que seus autores jamais tenham se lido mutuamente; encontramos, também, histórias parecidas em povos diferentes, de épocas diferentes. Por que as tragédias gregas ainda despertam nossa atenção? Porque o homem contemporâneo vivencia, no sonho ou na realidade, os mesmos temores do homem daqueles tempos longínquos: tem medo do castigo divino, receia ter ímpeto de cometer um infanticídio ou parricídio, acredita ser capaz de vencer a morte e resgatar o sujeito amado, desconfia que possa trair um amigo... Esse pensamento comum está alojado em alguma parte de nosso inconsciente, a que Jung chama de inconsciente coletivo. Por existirem sempre, e em toda parte, o psicólogo das profundezas diz ainda que, mesmo se cortássemos as tradições, a mitologia e a história das religiões, tudo isso recomeçaria com a geração seguinte..$^{30}$

Com as fantasias que cria e cultiva por meio da arte, do sonho e da religião, o homem vai encontrando equilíbrio para seu singular existir. Dora Ferreira da Silva afirma que
28. JUNG. Símbolos da transformação, p. XV.

29. JUNG. Símbolos da transformação, p. 21 
31. CICERO. A cidade e os livros: entrevista. o mito nos coloca em contato com nós mesmos e com a natureza porque ele age como a raiz de uma árvore: vai lá no fundo (inconsciente) buscar o sustento, o alimento, e lá no fundo está nosso ser criança, nossa vida primitiva que permaneceu intocada.

Ao longo da história da arte, os mitos gregos sempre foram revisitados porque são mensageiros de histórias exemplares da condição humana, esta que jamais se perde no tempo. Antonio Cicero, poeta contemporâneo, fala da sempre atualidade do panteão grego, que também encontra lugar em sua obra: "Toda a literatura clássica é, por direito, nosso patrimônio. Tâmiris, Dédalo, Ícaro etc. são elementos do vocabulário moderno. É por isso que os uso quando me convém fazê-lo". ${ }^{31}$ Dora Ferreira da Silva era neta de gregos, daí seu apreço aos deuses desse povo - a mitologia grega -, mas, de igual forma, a poeta se interessou por mitos de outras culturas, como a egípcia e a judaico-cristã. Em entrevista, a poeta fala que os deuses gregos se "imiscuem" (misturam) à sua sensibilidade artística. Talvez, também, como declarou Antonio Cicero, de vido ao apelo estético que aquelas imagens exercem sobre todos os artistas. Mário de Andrade, antes de Macunaíma e Clã do jabuti, não deixa de evocar mitos gregos no "Prefácio interessantíssimo" de sua Paulicéia desvairada, em plena defesa de uma literatura brasileira moderna: "novo Anfião moreno e caixa-d'óculos, farei que as próprias pedras se reúnam em muralhas à magia do meu cantar. E dentro dessas muralhas esconderemos nossa tribo".$^{32}$ Portanto, nosso primitivismo haveria de pagar tributo ao paradigma antropológico que desconsidera tempo e lugar, o arquétipo - no caso, o da criação literária -, força universal que cada cultura expressa por meio de símbolos e mitos próprios. Vindos de uma longa tradição cultivada pelas artes ocidentais, os mitos gregos nunca perderam sua força imagética nem a riqueza simbólica de infundir significados, por isso são sempre contemporâneos, conforme ainda se lê no Prefácio: "Sei mais que pode ser moderno artista que se inspire na Grécia de Orfeu”. ${ }^{33}$

\section{OLHANDO PARA TRÁS}

Dois poemas de Dora Ferreira da Silva a Guimarães Rosa nasceram de forma singular, a partir de uma fotografia: "Quando pedimos uma foto, mandou uma em que estava vestido esportivamente, montado em um cavalo e olhando para trás. Foi a partir dessa foto que escrevi o poema 'A Guimarães Rosa', que está em Andanças". ${ }^{34}$

\section{A Guimarães Rosa}

a vida também é para ser lida

G.R
32. ANDRADE. Poesias completas, p. 76

3. ANDRADE. Poesias completas, p. 74.

34. GALVÃO. Entrevista de Dora Ferreira da Silva. 
35. SILVA. Andanças, p. 106-107

36. ROSA. Ficção completa, p. 70.
Rosa, contador de estórias

que arrepiam a alma a contrapelo.

Nasceste um dia,

mas a noite não marcou teu fim.

Recomeças.

És a Estória que sempre ouvimos

contando o que não se acaba.

Principia no fim.

Em círculo, ouvias sob a lua

o que recontarias

com palavras semeadas,

mortas-ressuscitada

na glória final do Poema.

Tudo começa contigo, de algum modo,

neste grande desabrigo

que começa e recomeça

sob a asa do teu Poema.

Leste a mão da nossa terra?

Traçaste o mapa completo da vida

em cartografia?

Rosa, Rosa, sempre Rosa -

quiromante do sertão. ${ }^{35}$

Guimarães Rosa falou sobre a possibilidade da "morte da poesia verdadeira" quando esta passa pela obediência ao verso, pela "lei das regras chamadas poéticas". ${ }^{36}$ Rosa ainda vai dizer que o dicionário é "a melhor antologia lírica", porque "cada palavra é, segundo sua essência, um poema”. ${ }^{37}$ De igual modo, Dora Ferreira da Silva se esquivava das formas fixas, as quais considerava "aprisionantes". Lembra que, conforme lhe escrevera Gerardo Mello Mourão, "a poesia joga com as formas, não com a fôrma”. ${ }^{38}$ Daí que, na concepção da poeta, toda a obra do mineiro seja um Poema, e poema rumo ao cimo, porque tem asa. No imaginário de Dora, a poesia é um pássaro-poema. E quantas sublimidades não inspirou o Manuelzinho-da-crôa? Em Rosa, mapas e círculos circunscrevem a caminhada do homem rumo ao cimo, cuja imagem do pássaro é emblemática. Pelo tanto de invenção, poesia e ensinamentos, Dora proclama: "João Guimarães Rosa, bardo do Brasil, inventor de mundos, a nossa paidéia, o nosso Homero" ${ }^{39}$

A fotografia desperta em Dora o fabulista da alma e seus reveses, das Estórias de arrepiar, porque plenas das verdades humanas, as mais sublimes e as mais terríveis. Assim como a consagração da alegria, Rosa trouxe o demoníaco e todas as suas hierofanias horripilantes, resgatando uma longa tradição de se avizinhar do mal, mas jamais feita aqui no Brasil de forma tão contundente como a impressa em Grande sertão: veredas. Pela alquimia do verbo, Rosa revigorou a literatura e provocou a alma de seus leitores. Esse homem erudito, de personalidade imponente, que conduziu uma boiada e se lançou a um criatório de palavras selvagens e pétreas,
37. ROSA. Fiç̧ão completa, p. 70

38. GALVÃO. Entrevista de Dora Ferreira da Silva.

39. SILVA. Às margens de Rosa, p. 59 
também portava a delicadeza do nome, por isso Dora o eterniza pela imagem da rosa singular que não fenece ao fim do (longo) dia. Assim, para Dora, Rosa já é um mito a expressar o arquétipo do fabuloso, que ele mesmo vivenciara de forma vibrante: "às vezes quase acredito que eu mesmo, João, sou um conto contado por mim mesmo". 40

A circularidade que faz de cada fim um recomeço - o mandala ou a lemniscata (o oito deitado) do final de Grande sertão: veredas - como está bem posto na obra de Rosa, aqui também se aplica à vida do amigo, que não cedeu à noite, que se faz a própria estória contada e que reconta o escutado, uma referência à oralidade que tanto fundamenta a obra do mineiro, como traduz a figuração xamânica do autor. As noites enluaradas que inspiram violeiros e cantadores e o domínio agrolunar que rege o homem do sertão também favorecem o plantio da palavra que, tal como a semente, pelas mãos alquímicas e agricultoras de Rosa - que choca, garimpa, enxerta e lava cada palavra - ganha vida nova. $\mathrm{O}$ resultado é que a densidade estética da obra rosiana não é outra coisa senão um Poema e sua capacidade fundante e instauradora de vida. Conferindo ao escritor mineiro o atributo de decifrar os sinais do mundo, na bela imagem do quiromante que lê a mão da terra, a poeta concebe o Poema de Rosa como um acolhimento ao desamparo humano, uma vez que é potência reveladora.
Uns vinte anos depois da visita inesperada e da foto que inspirou o primeiro poema, Dora Ferreira da Silva reencontra a fotografia enviada pelo amigo:

A poeta revive a visita longínqua, explorando agora a imagem que tem em mãos, demorando sobre o detalhe do

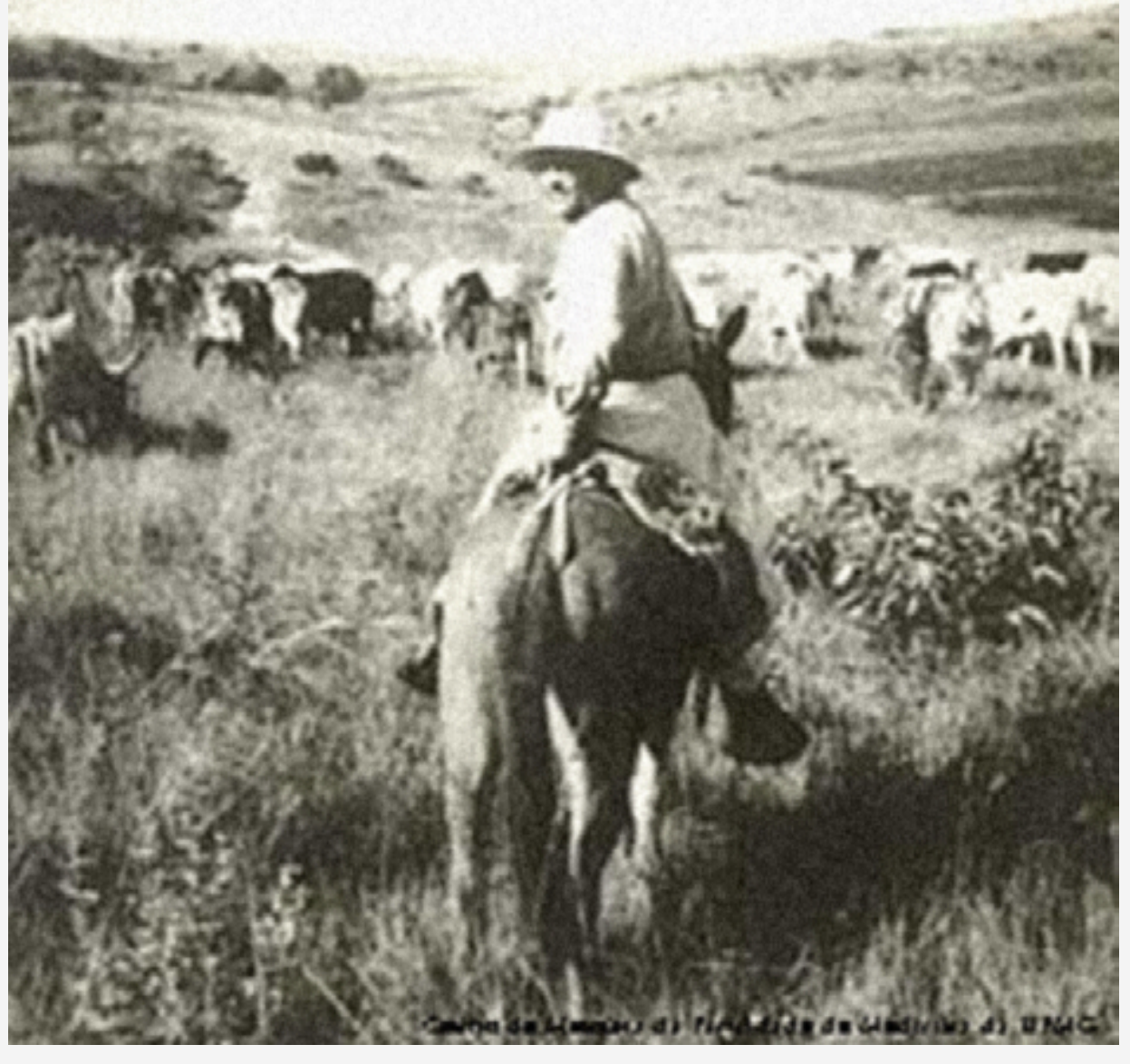

FIGURA 1
FIGURA 1

Foto: João Guimarães Rosa, na viagem ao Sertão Mineiro em 1952 fotografado por Eugênio Silval revista O Cruzeiro. (Acervo: Fundo João Guimarães Rosa - Arquivo do Instituto de Estudos Brasileiros USPI
EM TESE
BELO HORIZONTE
v. 22
N. 2
MAIO-AGO. 2016
SOUZA. "Você é a Dora? Eu sou o Guimarães Rosa”: encontros míticos [...] P. 157-174 
escritor que "olha para trás", montado no cavalo. O poema é tecido a partir dos tempos se cruzando: o da poeta que vê a foto recuada no tempo, e o do olhar do escritor mais recuado ainda, olhando um "atrás" indelineável, perdido no infinito. A poeta se coloca como a "Eurídice viva" deste que não é "Trácio nem Orfeu”, e inveja os que já habitam o "rancho dos bem-aventurados". O título do poema, inserido na obra Jardins (esconderijos), de 1979, é "Fotografia de Guimarães Rosa":

\section{A boiada}

e o chifre apontando da primeira lua.

Olhas o quê? Para trás.

Nem Trácio nem Orfeu

olhas o deixado:

ninguém ou Eurídice

algo que te retém.

O sorriso sob o sol

ao léu

na paisagem áspera:

flancos e suores

árvores e cardos

tardo o passo

o dia cansado. ${ }^{41}$
Ao tempo em que insere algumas conjeturas sobre o que Rosa procura com o olhar para trás, a poeta descreve o espaço da cena: o sol, o suor, a vegetação, a boiada seguindo lenta, o surgimento da lua. O compasso binário dos versos finais dessa primeira estrofe, "flancos e suores / árvores e cardos / tardo o passo / o dia cansado" mimetizam o trote cansado dos bois que se estende ao dia agonizante. As assonâncias do "a", cuja marcação forte se faz na primeira sílaba, também sugerem a monotonia do passo lerdo e pesado. O fim da jornada se anuncia pela imagem do chifre do boi, imagem esta que é sugestiva da lua crescente, aquela que, dentro de sua fase, surge à tarde e pouco após o pôr do sol. A mescla da lua com o sol - da claridade com as trevas, da noite com o dia, da morte com a vida - é propícia ao cenário da fusão entre os dois mundos que separam a personagem Rosa do sujeito-lírico. De igual modo, a conjunção da luz com as trevas evoca Orfeu e Eurídice, quando o poeta Trácio vasculha o mundo das sombras atrás da amada, não a resgatando de lá por conta de sua desmedida, violando a interdição de não olhar para trás. É por essa trilha simbólica que o poema caminha: Rosa é Orfeu, mas é Rosa, porque não é "Trácio nem Orfeu". Assim como o poeta herói, Rosa habita uma indefinição geográfica que o eleva a um espaço e tempo sagrados. Tudo procurava esse fabulista que vivia face a face com o infinito. Na próxima estrofe, o sujeito-lírico assume a persona de Eurídice: 
42. SILVA Jardins (esconderijos), p. 116.

43. ROSA. Ficção completa, p. 73.
É um reencontro casual

de fotografia.

Defronto o olhar para trás

muralha de pupilas

onde assumo

posição nenhuma.

Não sabes que me vês

que recolho

o vôo de teus olhos

em campo aberto.

(Uma sombra bulia ali por perto?) $)^{42}$

Essa estrofe fala de reencontro, olhar, posição física, sombra, tudo isso entrevisto pela fotografia, agora espaço do mito. Orfeu reencontrou-se com Eurídice, mas não pôde vê-la. De igual modo, o reencontro casual com a foto é um encontro de morto com vivo, em que os olhares cruzados formam uma "muralha" intransponível entre os mundos. Os versos finais dessa estrofe, a partir de "Não sabes que me vês", acentuam ainda mais a presença do sujeito-lírico nesse poema fortemente centrado no eu poético, o qual assume o pape do poeta Trácio não só pela aventura de resgatar um morto ao mundo avernal, mas pelo poder encantatório de sua linguagem poética, a única capaz de recolher "o vôo de teus olhos / em campo aberto”. Rosa declarou várias vezes seu horror ao momento, pois só o infinito o interessava, uma vez que "se sente no infinito como se estivesse em casa". ${ }^{43}$ Vê-se que sua vontade é atendida no poema. A imagem do "campo aberto" redimensiona o espaço da boiada e seu boiadeiro para o infinito. Mas no olhar para trás do escritor mineiro está a presença da morte misteriosa que também é vislumbrada pela "sombra" escondida detrás da moita, que "bulia ali por perto". Mas também os papéis podem se inverter: prisioneiro "do rancho dos bem aventurados”, o eu poético se faz Eurídice, a sombra que espreita pela moita o bem-amado, transpondo mundos, alterando o regime dos mortos e dos vivos:

Entrei tarde demais nesta fotografia.

Outro era o dia outro

o mundo.

Quem sabe um boi mugia

no momento completo.

Eurídice havia

que olhasses recuando para o Hades?

Para trás - teu sorriso aqui está

morto por zombaria

pseudo-morto

olhando Eurídice viva

cativa do rancho dos bem-aventurados. ${ }^{44}$

A fotografia concentra o mito da separação, da morte, da nostalgia, do desencontro temporal entre os que ficam e os que se foram, ou dos que se conheceram em tempos fora do tempo ideal. Critica-se Orfeu pelo seu demasiado apego à
44. SILVA Jardins (esconderijos), p. 117.
EM TESE
BELO HORIZONTE
v. 22
N. 2
MAIO-AGO. 2016
SOUZA. "Você é a Dora? Eu sou o Guimarães Rosa": encontros míticos [... ] P. 157-174 
45. BRANDÃO. Dicionário míticoetimológico, p. 199. matéria, por sua volta ao passado, sempre imperfeito: "para trás é o regresso ao passado, às hamartíai, às faltas, aos erros, é a renúncia ao espírito e à verdade" ${ }^{45}$ Mas a poeta fala é do tempo do infinito no qual vivia Rosa, tempo de "outro mundo", de um "momento completo", muito além de um simples passado, momento em que o mugido do boi arrasta para um tempo primordial. Nesse tempo, a personagem não está morta, e o sujeito-poético tem acesso a seu mundo encantado. A poeta tira proveito do "olhar para trás", que tanto lhe serve como imagem poética como representa um gesto pontual da personagem da fotografia, quem sabe até mesmo representado, ensaiado. Considerando a referência histórica da imagem fotográfica, quem sabe, se a foto tivesse sido feita antes do encontro na casa da rua José Clemente, Rosa-Orfeu não estivesse olhando para ela, Dora-Eurídice, esta Eurídice viva, fascinada pelo mundo dos mortos, agora não mais o Hades, mas a morada dos bem-aventurados onde o vaqueiro estabeleceu seu rancho? Rosa olha para ela que, fisicamente, está nesse mundo de cá, mas que sempre acreditou na possibilidade do trânsito entre morte e vida, transformando, pela poesia, o efêmero em perene. Viver na mesma dimensão do infinito, essa é a única forma de resgatar o tempo primordial, a felicidade dos mundos transponíveis. Só com a morte Orfeu encontra sua Eurídice: "Perambulando pelos Campos dos abençoados, encontrou Eurídice, / E a tomou em seus braços, eles passeiam agora. Orfeu a segue / Ou caminha à frente dela, e pode, com total segurança, / Olhar para trás em busca de sua Eurídice". ${ }^{46}$

Ao longo de sua carreira como poeta, tradutora e conferencista, Dora Ferreira da Silva escolhia escritores e temas que apresentassem afinidade com sua visão de mundo, eleição que a levou a criar uma "família espiritual", o que favorece estudos aproximativos desses escritores com sua obra poética. À sua família espiritual, a poeta dedica poemas, como o faz para Guimarães Rosa. O encontro com o escritor mineiro foi arrebatador, e não mais se distanciaram, afinal eram almas que amavam refletir sobre a condição humana a morte, o indizível, o inexplicável - pelo viés da religião, da filosofia e da palavra. Havia o mútuo fascínio pela concepção do universo como unidade simbólica em que a poesia se põe em comunicação com o mistério da existência e a linguagem retoma sua potência de instaurar o tempo do mito.

\section{REFERÊNCIAS}

ANDRADE, Mário de. Poesias completas. Belo Horizonte: Itatiaia; São Paulo: EDUSP, 1987.

BRANDÃO, Junito. Dicionário mítico-etimológico. Petrópolis: Vozes, 1991.v. 2

CICERO, Antonio. Entrevista - a cidade e os livros. Disponíve em: <http://www2.uol.com.br/antoniocicero/storm.html> Acesso em fev. 2014. 
CRIPA, Adolpho. Mito e cultura. São Paulo: Convívio, 1975.

ELIADE, Mircea. O sagrado e o profano. São Paulo: Martins Fontes, 2008.

ELIADE, Mircea. Mito e realidade. São Paulo: Perspectiva, 1972.

GALVÃO, Donizete. Entrevista de Dora Ferreira da Silva. Jornal de Poesia. Revista Cult - Maio / 99. Disponível em: < http://www.jornaldepoesia. jor.br/dgp5.html > e < http://arte-vida-poesia.blogspot.com/2011/04/doraferreira-da-silva-entrevista.html>. Acesso em 18 jan. 2016.

GALVÃO, Donizete; MARTINS, Floriano. Dora Ferreira da Silva: diálogos sobre poesia e filosofia, recordando Vicente Ferreira da Silva. Revista Agulha, Fortaleza; São Paulo, outubro de 2003. Disponível em: <http:// www.revista.agulha.nom.br/ag36silva.htm>. Acesso em: 18 jan. 2016

JUNG, Carl Gustav. Psicologia e poesia. In: 0 espírito na arte e na ciência. Tradução de Dora Ferreira da Silva, Ruben Siqueira Bianchi. Petrópolis: Vozes, 1991. p. 73-93.

JUNG, Carl Gustav. Símbolos da transformação. Tradução de Eva Stern (Dora Ferreira da Silva é da comissão responsável pela tradução). Petrópolis: Vozes, 1989.

NERY, Hermes Rodrigues. Dora Ferreira da Silva: a fascinação do mito. PenAzul - Literatura e Arte, 02 dez. 1989. Disponível em: $<$ http://medei.sites.uol.com.br/penazul/geral/entrevis/dora.htm>. Acesso em 10 ago. 2011.

OLIVEIRA, Franklin de. Revolução Rosiana. In: COUTINHO,

Eduardo (Org.). Guimarães Rosa. Fortuna crítica. Rio de Janeiro:

Civilização Brasileira, 1991. p. 179-186.
OVIDIO. Metamorfoses. Trad. Vera Lúcia Leitão Magyar. São Paulo: Madras, 2003.

ROSA, João Guimarães. Diálogo com Guimarães Rosa, por

Gunter Lorenz. In: ROSA, João Guimarães. Ficção completa. Rio de Janeiro: Nova Aguillar, 1994. v. 2.

SILVA, Dora Maria Ferreira da. Transpoemas. São Paulo: Instituto Moreira Salles, 2009.

SILVA, Dora Maria Ferreira da. Às margens de Rosa. Cadernos de literatura brasileira - João Guimarães Rosa, Rio de Janeiro, n. 20-21, dez. 2006

SILVA, Dora Maria Ferreira da. Jardins (esconderijos). São Paulo: Ed. da autora, 1979.

SILVA, Dora Maria Ferreira da. Andanças. São Paulo: Ed da autora, 1970

SILVA, Dora Maria Ferreira da. Cavalo Azul 1 .São Paulo: Ed. da autora, 1964/1965.

SILVA, Dora Maria Ferreira da. O demoníaco em Grande Sertão: Veredas. Dialogo, n. 8, 1957, p. 29-33.

SILVA, Dora Ferreira da; LEPARGNEUR, Hubert. Angelus Silesius: a mediação do nada. São Paulo: T. A. Queiroz, 1986.

SOUZA, Enivalda Nunes Freitas e. Flores de Perséfone: a poesia de Dora Ferreira da Silva e o sagrado. Goiânia: Cânone Editorial; Belo Horizonte: FAPEMIG, 2013.
EM TESE
BELO HORIZONTE
v. 22
N. 2
MAIO-AGO. 2016

SOUZA. "Você é a Dora? Eu sou o Guimarães Rosa”: encontros míticos [...] P. 157-174 